\title{
Peran Koperasi Sekolah dalam Menumbuhkan Jiwa Wirausahawan pada Diri Siswa
}

\author{
Ni Wayan Suparmi ${ }^{* 1}$, Kadek Rai Suwena ${ }^{2}$, Made Ary Meitriana ${ }^{3}$ \\ Program Studi Pendidikan Ekonomi \\ Universitas Pendidikan Genesha \\ Singaraja, Indonesia
}

Email: suparmiwayan8@gmail.com *1, rai_suwena@undiksha.ac.id ${ }^{1}$, ary.meitriana@undiksha.ac.id ${ }^{2}$

Pengutipan:

Suparmi, N. W.,

Suwena, K. R. \& Meitriana, M. A. (2020). Peran

Koperasi Sekolah dalam

Menumbuhkan

Jiwa

Wirausahawan

pada Diri Siswa.

Jurnal Pendidikan

Ekonomi

Undiksha, 12 (1),

68-77

\begin{abstract}
Abstrak
Riwayat Artikel Tanggal diajukan: 25 Oktober 2019

Tanggal diterima : 4 Juni 2020

Tanggal dipublikasikan: 29 Juni 2020

Tujuan dari penelitian ini untuk mengetahui peran koperasi sekolah dalam menumbuhkan jiwa wirausaha pada diri siswa di SMK Negeri 1 Gianyar. Jenis Penelitian ini adalah penelitian deskriptif, teknik pegumpulan data menggunakan kuesioner dan dokumentasi. Populasi dalam penelitian ini yaitu siswa Jurusan Pemasaran SMK Negeri 1 Gianyar berjumlah 208 siswa dengan jumlah sampel menjadi 137 orang mengunakan teknik sampel random sampling. Analisis data yang digunakan adalah analisis deskriptif. Hasil penelitian menunjukkan bahwa peran koperasi sekolah ditinjau dari dimensi membentuk praktik penyelamatan yang baik dan independen memperoreh skor 2.220 dengan presentase skor sebesar $81,0 \%$. Hal ini berada pada kategori berperan sangat kuat. Ditinjau dari dimensi membantu dalam mewujudkan suasana latihan langsung untuk mempraktikan teknik-teknik pengurusan dan perdagangan memperoleh berada pada kategori berperan sangat kuat. Ditinjau dari mempunyai sifat-sifat serta unsur-unsur demokrasi di kalangan generasi muda berada pada kategori berperan sangat kuat. Ditinjau dari dimensi menggalakkan sikap bekerjasama serta saling bantu membantu antara satu sama lain berada pada kategori berperan sangat kuat. Dan ditinjau dari dimensi menumbuhkan bakat kepemimpinan di kalangan generasi muda berada pada kategori berperan sangat kuat.
\end{abstract}

Kata kunci: jiwa wirausahawan; koperasi sekolah; siswa wirausaha

\begin{abstract}
The purpose of this study was to determine the role of school cooperatives in fostering entrepreneurial spirit among students at Vocational High School Number 1 Gianyar. This type of research was descriptive research, the data collection instruments was using questionnaires and documentation. The populations in this study were students in marketing major at Vocational High School Number 1 Gianyar with the amount of 208 students with a total sample of 137 people using random sampling techniques. This research used descriptive analysis to analyze data. The results of data analysis showed that the role of school cooperatives in terms of the dimensions of forming good and independent rescue practices was in the category of very strong roles, in terms of the dimensions helping in realizing an atmosphere of direct training to practice techniques management and trade techniques in the category of very strong roles, in terms of having the characteristics and elements of democracy among the younger generation in the category very strong role, in terms of the dimensions of promoting cooperation attitude and mutual assistance to help each other were in the category of very strong role, and in terms of the dimension of growing leadership talent among the younger generation scores 4,109 with the percentage score of $85.6 \%$ was very strong category.
\end{abstract}

Keywords: entrepreneurship; school cooperatives, entrepreneurial student 


\section{PENDAHULUAN}

Pada zaman globalisasi saat ini, penting untuk menumbuhkan jiwa wirausaha, dimana di Indonesia jumlah wirausaha sangat terbatas dan masih tergolong sedikit (Alma, 2004). Mengenalkan jiwa wirausahawan sejak dini kepada generasi muda merupakan hal yang sangat baik untuk dilakukan, generasi muda akan mendapatkan kesempatan lebih luas dalam mengembangkan

keterampilan

berwirausaha. Salah satu tempat yang bisa menjadi wadah siswa untuk menumbuhkan jiwa wirausahawan adalah melalui sekolah (Tando, 2013). Melalui sekolah siswa mendapatkan pendidikan yang lebih lengkap dan mendasar, dimana pendidikan menjadi hal yang sangat penting di Indonesia untuk mengembangkan kualitas sumber daya yang kompeten (Sapka \& Marazaenal, 2019). Dalam menumbuhkan jiwa wirausaha di sekolah, maka perlu di dukung oleh dikurikulum, tenaga pengajar, prasarana dan sarana atau fasilitas, metode dalam pembelajaran, laboratorium, dan lingkungan sekolah. Sarana pendukung yang ada di sekolah akan dapat memudahkan siswa dalam mengembangkan kemampuan dalam berwirausaha. Salah satu upaya yang dapat dilakukan sekolah adalah tersedianya koperasi sekolah.

Koperasi sekolah merupakan koperasi yang anggotanya masih belum dewasa dan perlu bimbingan dari guru. Menurut Ismail (2004) koperasi sekolah yaitu bagian dari kurikulum yang menjadi salah satu pengetahuan untuk siswa. Koperasi sekolah dapat menjadi tempat pelatihan kepada siswa untuk mengekspolasi potensi yang mereka miliki yang tidak bisa mereka dapatkan dalam pelajaran di kelas (Cantisa, Herkulana, \& Khosmas, 2019). Koperasi sekolah dibangun untuk mengembangkan kemapuan siswa untuk mandiri dan terampil dalam berwirausaha. Maka dengan adanya koperasi sekolah siswa dapat berekembang dan menumbuhkan jiwa wirausahawan. Menurut Sukidjo, Muhson, \& Mustofa (2016) koperasi sekolah diwujudkan dalam bentuk merencanakan sejak dini mental dan jiwa wirausahawan pada diri siswa yang dapat dimulai dari bangku Sekolah Dasar sampai Mengengah Atas dengan menyediakan suatu pilihan untuk menjadi pencari kerja atau mampu membuka lapangan pekerjaan sendiri sebagai seorang wirausaha.

Koperasi sekolah memiliki peranan yang penting. Menurut Ismail (2004) peranan koperasi sekolah adalah sebagai berikut. Pertama, membentuk praktik penyelamatan yang baik dan independen dimana siswa harus memiliki sikap mandiri, dan mamapu merencanakan pengeluaran. Kedua, membantu dalam mewujudkan suasana latihan langsung untuk mempraktekkan teknik-teknik pengurusan dan perdagangan, dalam hal ini koperasi sekolah memberikan pelatihan kepada siswa dalam pelajaran perdagangan, pembukuan dan keusahawanan di sekolah, siswa dapat memahirkan diri dalam kegiatan yang dijalankan sebelum keluar dari sekolah, siswa dilatih untuk berpikir kreatif dan menghindari bisnis yang tidak sehat. Ketiga, mempunyai sifat-sifat serta unsur-unsur demokrasi di kalangan generasi muda yaitu, adanya rasa toleran dikalangan siswa, melakukan interaksi antar sesama, dan memiliki sikap tanggung jawab. Keempat menggalakkan sikap bekerjasama serta saling bantu-membantu antara satu sama lain yaitu, adanya sikap persatuan, percaya, sikap positif dan setia kawan. Kelima, menumbuhkan bakat kepemimpinan di kalangan generasi muda yaitu, mempertahankan hak, dapat berpikir rasional dan berani mengemukakan pendapat.

Menurut Cantisa, Herkulana, \& Khosmas (2019) koperasi sekolah meliputi tiga aspek yaitu, pertama mengembangkan jiwa setia kawan, saling menghargai, dan gotong royong antar sesama, kedua menanamkan rasa demokrasi, kreativitas, ketiga memasyarakatkan koperasi melalui pendidikan ekonomi.

Koperasi sekolah dapat didirikan pada Sekolah Dasar, Sekolah Menegah Pertama, Sekolah Menengah atas atau Kejuruan dan Perguruan Tinggi. Koperasi sekolah memiliki dua tujuan yaitu, ditinjau dari aspek pendidikan yaitu, siswa akan mendapatkan pengetahuan dalam perkoperasian dan ditinjau dari aspek wiraswata, yaitu siswa mendapatkan praktek untuk mengenal dalam hubungan dagang. Menurut Sapka \& Marazaenal (2019) koperasi sekolah memiliki sasaran untuk mengenalkan siswa 
dalam pengetahuan koperasi dan menanamkan perilaku yang positif dalam memberikan modal keterampilan kewirausahaan.

Dalam pelaksanaan koperasi sekolah memerlukan usaha secara nyata yang dilakukan oleh siswa dan usaha tersebut dapat mencerminkan asas dari koperasi yaitu, berlandaskan kekeluargaan dan gotong royong untuk mencapai tujuan bersama (Lindawati Margareta Lilis \& Suyanto, 2015). Pelaksanaan koperasi sekolah adalah salah satu wadah yang berfungsi sebagai tempat pembelajaran bagi siswa untuk praktek dan mengembangkan keterampilan berwirausaha lebih maksimal.

Kegiatan usaha koperasi sekolah yaitu untuk mendapatkan keterampilan dalam berusaha, dimana kegiatan usaha koperasi sekolah meliputi beberapa kegiatan ekonomi yaitu, menjual alat-alat kebutuhan yang diperlukan oleh siswa dan guru, menjual alat-alat tulis atau pelatan sekolah, kebutuhan alat-alat mandi, seragam sekolah, dan makan maupun minuman. Kegiatan tersebut dilakukan untuk mengenalkan kepada siswa dalam berwirausaha.
Sekolah yang tepat untuk keberadaan koperasi sekolah adalah sekolah Menengah Kejuruan. Menurut Kurniawan (2014) Sekolah menengah kejuruan adalah salah satu lembaga pendidikan yang berbeda dari sekolah umum, dimana pada sekolah kejuruan siswa mendapatkan mata pelajaran produktif sesuai dengan minat siswa.

SMK Negeri 1 Gianyar merupakan salah satu sekolah yang memiliki sarana prasarana yang lengkap dalam menunjang proses belajar siswa salah satunya adalah koperasi sekolah. Koperasi sekolah merupakan salah satu laboratorium usaha yang dimanfaatkan oleh siswanya. Dimana koperasi sekolah ini dikelola oleh guru dan siswa SMK Negeri 1 Gianyar, untuk praktek di koperasi sekolah hanya siswa dari Jurusan Pemasaran, karena sesuai dengan program keahlianya. Jurusan lain yang ada di sekolah juga memiliki laboratorium sendiri untuk praktek yang sesuai dengan program keahliannya.

Jumlah dari siswa Jurusan Pemasaran dari kelas 1 sampai kelas 3 adalah 208 siswa. Dari jumlah tersebut guru membentuk jadwal piket yang diberikan kepada siswa untuk praktek di koperasi sekolah. Berikut disajikan pada tabel 1

Tabel 1. Jumlah Siswa Jurusan Pemasaran yang Piket di Koperasi Sekolah

\begin{tabular}{ccccc}
\hline Kelas & PMS1 & PMS2 & Hadir & Tidak Hadir \\
\hline 1 & 38 & 34 & 69 & 3 \\
2 & 32 & 35 & 64 & 3 \\
3 & 35 & 34 & 67 & 2 \\
\hline
\end{tabular}

Sumber: SMK Negeri 1 Gianyar

Berdasarkan tabel diatas terdapat beberapa siswa yang tidak mengikuti piket ini. Hal ini disebabkan karena kurangnya kesadaran siswa dalam mengikuti piket. Tujuan dari adanya piket ini adalah untuk dapat menumbuhkan jiwa wirausahawan pada diri siswa dan siswa siap untuk menjadi tenaga kerja yang terampil dan kompeten di tingkat menengah, seperti dibidang pramuniagaan, sales excutive, dan mampu menjadi seorang wirausaha yang handal serta dapat membuka lapangan pekerjaan sendiri.

Keberadaan koperasi sekolah akan mendorong siswa untuk dapat menumbuhkan motivasi dalam berwirausaha, yaitu siswa dapat mengembangkan keterampilan wirausaha yaitu, membuat pembukuan, pencatatan persediaan, mengoperasikan komputer, melayani pembeli serta kegiatan kewirausahaan lainnya, dan siswa dilatih untuk mandiri, dapat bekerja sama dalam kelompok, bertanggung jawab, taat akan aturan dan memiliki semangat yang tinggi (Kurniawan, 2014).

Menjadi seorang wirausaha harus bisa menyediakan waktunya mengatur kegiatan bisnisnya. Menurut Meredith (2000) wirausaha adalah individu-indivu yang mengarah kepada tindakan, dan memiliki motivasi yang tinggi untuk mencapai suatu tujuan. Menjadi seorang wirausaha harus berani dalam menembus sistem ekonomi 
dengan menghadirkan barang atau jasa baru, serta mampu menciptakan bentuk organisasi baru yang akan dapat membuka lapangan pekerjaan baru bagi masyarakat. Menurut Kasmir (2014) wirausahawan (entrepreneur) adalah orang yang memiliki jiwa berani dalam mengambil keputusan dan resiko dalam berwirausaha, ini artinya mereka memiliki mental mandiri dan percaya diri untuk memulai usaha tanpa diliputi rasa takut atau khawatir dalam kondisi tidak pasti yang akan dihadapi oleh seorang wirausahawan.

Seorang wirausahawan selalu berpikir bagaimana cara untuk dapat memberi keuntungan dengan membuka lapangan pekerjaan sendiri. Sehingga wirausahawan merupakan orang yang berani dalam memanfaatkan peluang dan berani mengambil resiko yang ada dalam menciptakan usaha sendiri.

Seseorang wirausahawan memiliki karakteristik yang berbeda, menurut Meredith (2000) ciri-ciri seorang wirausaha yaitu, pertama, percaya diri adalah sifat kepercayaan akan diri sendiri dan optimis. kedua, berorientasi pada tugas dan hasil yang memiliki sifat kerja keras, mengharapkan laba dan ulet dalam bekerja. Ketiga, berani mengambil resiko yang memiliki sifat suka pada tantangan. Keempat, kepemimpinan dimana seseorang mudah bergaul bisa menjadi pemimpin dan mau menerima saran atau kritikan dari orang lain. Kelima, keorisinilan yaitu kreatif, inovatif dan dinamis dalam membuka peluang. Keenam berorientasi pada masa depan yaitu memiliki pandangan untuk maju kedepan.

Setiap orang sudah dibekali jiwa kewirausahaan, dimana minimal seseorang harus mampu memenuhi kebutuhan dirinya sendiri, setelah itu meningkat untuk keluarganya. Selain untuk diri sendiri dan keluarga jiwa wirausaha pada diri siswa juga dibutuhkan oleh orang lain, karena dengan hal tersebut dapat terbukanya lapangan pekerjaan bagi orang lain. Jiwa wirausaha pada diri setiap individu berbeda-beda, jika jiwa wirausaha tidak dikembangkan, maka tidak akan bisa menjadi apa-apa, untuk mengembangkan dan menumbuhkan jiwa wirausaha bisa melalui pendidikan dan pelatihan dalam berwirausaha (Nurbudiyani, 2013).
Menurut Tando (2013) melalui pendidikan di sekolah seseorang mendapatkan pendidikan kewirausahaan, seperti proses dalam mengambil keputusan, meningkatkan keterampilan dan motivasi untuk berwirausaha. Dalam pendidikan kewirausahaan juga didukung oleh tenaga pengajar, prasarana dan sarana atau fasilitas, metode pembelajaran serta kondisi lingkungan yang mendukung untuk terwujudnya jiwa wirausaha siswa.

Berdasarkan pada uraian dari latar belakang diatas maka penulis tertarik mengkaji lebih jauh tentang koperasi sekolah dengan judul penelitian "Peran Koperasi Sekolah Dalam Menumbuhkan Jiwa Wirausahawan Pada Diri Siswa di SMK Negeri 1 Gianyar".

\section{METODE}

Jenis penelitian yang digunakan dalam penelitian ini merupakan penelitian deskriptif. Menurut Hikmawati (2017) penelitian deskriptif merupakan penelitian untuk mengumpulkan informasi mengenai status gejala yang ada dan tidak menguji hipotesis tertentu.

Penelitian ini menggunakan jenis data kuantitatif. Sumber data penelitian adalah data primer dan sekunder. Data primer dalam penelitian ini berupa jawaban kuesioner dari responden sedangkan data sekunder didapat dari pihak lain yaitu guru sekolah berupa nama-nama siswa yang piket di koperasi sekolah. Penelitian ini bertujuan untuk mendeskripsikan peran koperasi sekolah dalam menumbuhkan jiwa wirausahawan pada diri siswa di SMK Negeri 1 Gianyar.

Populasi dalam penelitian ini yaitu, siswa-siswi dari Jurusan Pemasaran SMK Negeri 1 Gianyar yang berjumlah 208 orang. Adapun teknik dalam pengambilan sampel menggunakan rumus Slovin (Umar, 2005) sebagai berikut.

$\mathrm{n}=\frac{N}{1+N e^{2}}$

Keterangan :

$\mathrm{n}=$ ukuran sampel

$\mathrm{N}=$ ukuran populasi

$\mathrm{e}=$ persen kelonggaran ketidaktelitian karena kesalahan pengambilan sampel yang 
masih dapat ditolerir atau diinginkan. kesalahan yang diberikan $0,05 \%$, maka jumlah sampel yang akan digunakan oleh peneliti dalam penelitian ini dapat dihitung sebagai berikut:

$$
\begin{aligned}
& N=208 \\
& E=0,05 \\
& S=\frac{208}{1+208\left(0,05^{2}\right)} \\
& n=\frac{208}{1+208(0,0025)} \\
& n=\frac{208}{1,52} \\
& n=136,84 \text { dibulatan menjadi } 137 .
\end{aligned}
$$

Sehingga sampel dalam penelitian ini berjumlah 137 orang, teknik pengambilan sampel dalam penelitian ini yaitu, menggunakan teknik random sampling. Teknik random sampling merupakan pengambilan sampel yang dilakukan secara acak sehingga semua anggota populasi memiliki kesempatan yang sama untuk menjadi sampel penelitian (Firdaus, M. Aziz, 2012)

Metode pengumpulan data dalam penelitian ini menggunakan, metode dokumentasi dan kuesioner. Metode dokumentasi digunakan untuk memperoleh nama-nama siswa Jurusan Pemasaran yang piket di koperasi sekolah di SMK Negeri 1 Gianyar, dan metode kuesioner digunakan untuk mengumpulkan data mengenai peran koperasi sekolah dalam menumbuhkan jiwa wirausahawan pada diri siswa di SMK Negeri 1 Gianyar. Kuesioner menggunakan skala likert dengan penskorannya dari skor tertinggi sampai skor terendah yaitu, sangat setuju diberi skor 5 , setuju diberi skor 4 , kurang setuju skor 3, tidak setuju skor 2, sangat tidak setuju skor 1. Sebelum kuesioner yang digunakan sebagai instrument dalam mengumpulkan data dilapangan, maka terlebih dahulu harus dilakukan uji tingkat validitas dan reabilitasnya.

Teknik analisis data yang digunakan adalah teknis analisis deskriptif. Analisis deskriptif digunakan untuk mendeskripsikan peran koperasi sekolah dalam menumbuhkan jiwa wirausahawan pada diri siswa di SMK Negeri 1 Gianyar. Menurut Riduwan (2008) langkah-langkah yang dilakukan dalam penelitian deskriptif adalah sebagai berikut.

Pertama mengelompokkan jawabanjawaban yang relevan dengan rumusan masalah penelitian, yang didapat dari jawaban kuesioner, kedua melakukan perhitungan angket yang diberikan kepada 137 orang siswa sebagai responden penelitian, ketiga menghitung angket dengan melakukan dua tahapan yaitu, pertama menentukan jumlah skor tertinggi $=$ (nilai tertinggi $\times$ jumlah item pertanyaan $\times$ jumlah responden), dan jumlah skor terendah $=$ (nilai terendah $\times$ jumlah item pertanyaan $\times$ jumlah responden), kedua mengitung presentase skor yaitu.

$$
\frac{\text { Jumlah Skor }}{\text { Skor Tertinggi }} \times 100 \%
$$

Kriteria interprestasi skor terlihat seperti pada tabel 2

Tabel 2. Kriteria Interprestasi Skor

\begin{tabular}{cc}
\hline Rentang Skor & Kategori \\
\hline $0 \%-20 \%$ & Sangat Lemah \\
$21 \%-40 \%$ & Lemah \\
$41 \%-60 \%$ & Cukup \\
$61 \%-80 \%$ & Kuat \\
$81 \%-100 \%$ & Sangat Kuat \\
\hline
\end{tabular}

Sumber: (Riduwan, 2008)

\section{HASIL DAN PEMBAHASAN}

Hasil Penelitian

Peran koperasi sekolah dalam menumbuhkan jiwa wirausahawan pada diri siswa di SMK Negeri 1 Gianyar ditinjau dari dimensi membentuk praktik penyelamatan yang baik dan independen yang menunjukkan hasil pada tabel 3 sebagai berikut. 
Tabel 3. Hasil Analisis Data Dimensi Membentuk Praktik Penyelamatan Yang Baik dan Independen

\begin{tabular}{lcccc}
\hline Dimensi & $\begin{array}{c}\text { Jumlah } \\
\text { Skor }\end{array}$ & $\begin{array}{c}\text { Jumlah } \\
\text { Skor Tertinggi }\end{array}$ & $\begin{array}{c}\text { Presentase } \\
\text { Skor( \%) }\end{array}$ & Kategori \\
\hline $\begin{array}{l}\text { Membentuk praktik } \\
\begin{array}{l}\text { penyelamatan yang baik } \\
\text { dan independen }\end{array}\end{array}$ & 2.220 & 2.740 & $81,0 \quad$ Berperan Sangat Kuat \\
\hline Total & 2.220 & 2.740 & 81,0 & Berperan Sangat Kuat \\
\hline
\end{tabular}

Berdasarkan pada tabel 3, maka dapat dijelaskan bahwa peran koperasi sekolah dalam menumbuhkan jiwa wirausahawan ditinjau dari dimensi membentuk praktik penyelamatan yang baik dan independen memperoleh skor 2.220 dengan presentase skor $81,0 \%$, yang berada pada kategori sangat kuat. Hal ini berarti koperasi sekolah memiliki peran yang sangat kuat dalam menumbuhkan jiwa wirausaha pada diri siswa di SMK Negeri 1 Gianyar.

Peran koperasi sekolah dalam menumbuhkan jiwa wirausahawan pada diri siswa di SMK Negeri 1 Gianyar ditinjau dari dimensi membantu dalam mewujudkan suasana latihan langsung untuk mempraktikan teknik-teknik pengurusan dan perdagangan menunjukakan hasil pada tabel 4 sebagai berikut.

Tabel 4. Hasil Analisis Data Dimensi Membantu Dalam Mewujudkan Suasana Latihan Langsung Untuk Mempraktikan Teknik-Tenik Pengurusan dan Perdagangan

\begin{tabular}{|c|c|c|c|}
\hline $\begin{array}{cc}\text { Dimensi } & \text { Jumlah } \\
& \text { Skor } \\
\end{array}$ & & $\begin{array}{l}\text { Skor } \\
\text { Tertinggi }\end{array}$ & $\begin{array}{r}\text { Presentase } \\
\text { Skor (\%) } \\
\end{array}$ \\
\hline $\begin{array}{l}\text { Membantu dalam mewujudkan } \\
\text { suasana } \\
\text { latihan langsung untuk mempraktikan } \\
\text { teknik-teknik pengurusan dan perdagangan }\end{array}$ & 4.069 & 4.79 & 84,8 Berperan Sangat Kuat \\
\hline Total 4.069 & 4.795 & 84,8 & Berperan Sangat Kuat \\
\hline
\end{tabular}

Berdasarkan pada tabel 4, dapat dijelaskan bahwa peran koperasi sekolah dalam menumbuhkan jiwa wirausahawan ditinjau dari dimensi membantu dalam mewujudkan suasana latihan langsung untuk mempraktikan teknik-teknik pengurusan dan perdagangan memperoleh skor 4.069 dengan presentase skor $84,8 \%$, hasil ini berada pada kategori sangat kuat, hal ini dapat diartikan koperasi sekolah memiliki peran yang sangat kuat dalam menumbuhkan jiwa wirausaha pada diri siswa di SMK Negeri 1 Gianyar.

Peran koperasi sekolah dalam menumbuhkan jiwa wirausahawan pada diri siswa di SMK Negeri 1 Gianyar ditinjau dari dimensi mempunyai sifat-sifat serta unsur-unsur demokrasi di kalangan generasi muda, menunjukkan hasil seperti pada tabel 5 sebagai berikut.

Tabel 5. Hasil Analisis Data Dimensi Mempunyai Sifat-sifat serta Unsur-Unsur Demokrasi di Kalangan Generasi Muda

\begin{tabular}{lcccc}
\hline Dimensi & $\begin{array}{c}\text { Jumlah } \\
\text { Skor }\end{array}$ & $\begin{array}{c}\text { Skor } \\
\text { Tertinggi }\end{array}$ & $\begin{array}{c}\text { Presentase } \\
\text { Skor (\%) }\end{array}$ & Kategori \\
\hline $\begin{array}{l}\text { Mempunyai sifat-sifat } \\
\text { serta unsur-unsur } \\
\text { demokrasi di kalangan generasi muda }\end{array}$ & $\begin{array}{c}3.483 \\
\text { Total }\end{array}$ & 4.110 & 84,7 & Berperan Sangat Kuat \\
\hline
\end{tabular}


Bersadarkan pada tabel 5, dapat dijelaskan bahwa peran koperasi sekolah dalam menumbuhkan jiwa wirausahawan ditinjau dari dimensi mempunyai sifat-sifat serta unsur-unsur demokrasi di kalangan generasi muda memperoleh skor 3.483 dengan presentase skor $84,7 \%$. Skor ini berada pada kategori sangat kuat, sehingga dapat disimpulkan bahwa koperasi sekolah memiliki peran yang sangat kuat dalam menumbuhkan jiwa wirausaha pada diri siswa di SMK Negeri 1 Gianyar.

Peran koperasi sekolah dalam menumbuhkan jiwa wirausahawan pada diri siswa di SMK Negeri 1 Gianyar ditinjau dari dimensi mengalakan sikap bekerjasama serta saling bantu membantu antara satu sama lain menunjukkan hasil penelitian pada tabel 6 sebagai berikut.

Tabel 6. Hasil Analisis Data Dimensi Menggalakkan Sikap Bekerjasama serta Saling Bantu Membantu antara Satu Sama Lain

\begin{tabular}{lcccc}
\hline Dimensi & $\begin{array}{c}\text { Jumlah } \\
\text { Skor }\end{array}$ & $\begin{array}{c}\text { Skor } \\
\text { Tertinggi }\end{array}$ & $\begin{array}{c}\text { Presentase } \\
\text { Skor (\%) }\end{array}$ & Kategori \\
\hline $\begin{array}{l}\text { Menggalakan sikap } \\
\text { bekerjasama serta } \\
\text { saling bantu membantu } \\
\text { antara satu sama lain }\end{array}$ & 3.540 & 4.110 & 86,1 & Berperan Sangat Kuat \\
\hline Total & 3.540 & 4.110 & 86,1 & Berperan Sangat Kuat \\
\hline
\end{tabular}

Berdasarkan pada tabel 6, maka dapat dijelaskan bahwa peran koperasi sekolah dalam menumbuhkan jiwa wirausahawan pada diri siswa di SMK Negeri 1 Gianyar ditinjau dari dimensi menggalakan sikap bekerjasama serta saling bantu membantu antara satu sama lain memperoleh skor 3.540 dengan presentase skor $86,1 \%$, berada pada kategori berperan sangat kuat, maka ini artinya koperasi sekolah memiliki peran yang sangat kuat dalam menumbuhkan jiwa wirausahawan pada diri siswa di SMK Negeri 1 Gianyar.

Peran koperasi sekolah dalam menumbuhkan jiwa wirausahawan pada diri siswa di SMK Negeri 1 Gianyar ditinjau dari dimensi menumbuhkan bakat kepemimpinan di kalangan generasi muda menunjukkan hasil penelitian dilihat pada tabel 7.

Tabel 7. Hasil Analisis Data Dimensi Menumbuhkan Bakat Kepemimpinan di Kalangan Generasi Muda.

\begin{tabular}{lllll}
\hline Dimensi & $\begin{array}{c}\text { Jumlah } \\
\text { Skor }\end{array}$ & $\begin{array}{c}\text { Skor } \\
\text { Tertinggi }\end{array}$ & $\begin{array}{c}\text { Presentase } \\
\text { Skor (\%) }\end{array}$ & Kategori \\
\hline $\begin{array}{l}\text { Menumbuhkan } \\
\text { bakat kepemimpinan } \\
\text { di kalangan generasi } \\
\text { muda }\end{array}$ & 4.109 & 4.795 & 85,6 & Berperan Sangat Kuat \\
\hline Total & 4.109 & 4.795 & 85,6 & Berperan Sangat Kuat \\
\hline
\end{tabular}

Berdasarkan pada tabel 7, dapat dijelaskan bahwa peran koperasi sekolah dalam menumbuhkan jiwa wirausaha pada diri siswa di SMK Negeri 1 Gianyar ditinjau Dari dimensi menumbuhkan bakat kepemimpinan di kalangan generasi muda, memperoleh skor 4.109 dengan presentase skor $85,6 \%$ berada pada kategori berperan sangat kuat, ini artinya koperasi sekolah memiliki peran yang sangat kuat dalam menumbuhkan jiwa wirausahawan pada diri siswa di SMK Negeri 1 Gianyar

\section{Pembahasan}

Hasil penelitian menunjukkan bahwa
peran koperasi sekolah dalam
menumbuhkan jiwa wirausahawan ditinjau
dari dimensi membentuk praktik
penyelamatan yang baik dan independen
berada pada kategori sangat kuat. Hal ini


berarti koperasi sekolah berperan sangat kuat dalam menumbuhkan jiwa wirausahawan pada diri siswa di SMK Negeri 1 Gianyar. Dalam menumbuhkan jiwa wirausahawan pihak sekolah membentuk piket yang dibuat untuk siswa jurusan pemasaran, kegiatan yang dilakukan siswa saat piket di koperasi sekolah seperti, siswa dilatih untuk mandiri, mendapatkan pelatihan dalam mengatur keuangan, dan berupaya membuat suatu kreatifitas dari hasil diri sendiri. Namun guru belum sepenuhnya memberikan kebebasan kepada siswa untuk belajar berwirausaha karena masih diawasi oleh guru. Sehingga siswa masih terbatas dalam mengembangkan kemampuan wirausahanya. Hal ini sejalan dengan pendapat Ismail (2004) menjelaskan bahwa siswa harus mampu berusaha sendiri tanpa mengharapakan bantuan orang lain dan menumbuhkan sikap pada siswa untuk merencanakan pengeluaran mereka.

Ditinjau dari dimensi membantu dalam mewujudkan suasana latihan langsung untuk mempraktikan teknik-teknik pengurusan dan perdagangan berada pada kategori sangat kuat, hal ini berarti koperasi sekolah berperan sangat kuat dalam menumbuhkan jiwa wirausahawan pada diri siswa di SMK Negeri 1 Gianya.

Koperasi sekolah memberikan siswa untuk praktek secara langsung, siswa menjadi pengurus dari koperasi sekolah dengan diawasi guru dalam mengelola usaha koperasi, siswa mendapatkan pelatihan perdagangan, menjadi seorang kasir, melakukan pengecekan dan menata barang yang akan di jual di koperasi sekolah, dalam pembukuannya siswa diajarkan untuk merekap penjualan dan belum sampai pada pembuatan laporan keuangan karena ini masih dikerjakan oleh guru. Hal ini sejalan dengan Ismail (2004) koperasi sekolah digunakan untuk berlatih teori yang dipelajari dari mata pelajaran perdagangan, pembukuan dan kewirausahaan di lingkungan sekolah.

Ditinjau dari dimensi mempunyai sifatsifat serta unsur-unsur demokrasi di kalangan generasi muda berada pada kategori sangat kuat, ini berarti koperasi sekolah memiliki peran yang sangat kuat dalam menumbuhkan jiwa wirausaha pada diri siswa di SMK Negeri 1 Gianyar.
Mengenalkan unsur demokrasi kepada generasi muda sangat penting dilakukan agar siswa mampu berorganisasi dalam suatu kelompok, bersikap toleran dengan teman, saling menghargai satu sama lain, dan siswa diajarkan untuk bisa berinteraksi dengan baik pada saat melayani pelanggan yang berbelanja di koperasi, maka guru memberikan siswa apresiasi. Dengan adanya apresiasi dari guru maka siswa sangat senang untuk melakukan tugas piket di koperasi sekolah.

Hal ini sejalan dengan pendapat Suwandi (1986) koperasi sekolah menanamkan rasa harga diri, membangun sikap berani mengemukakan pendapat kepada orang lain, dan koperasi sekolah dapat menjadi tempat untuk melatih mental siswa. Sehingga dengan adanya koperasi sekolah dapat mengembangkan dan membangun karakter siswa yang terdidik dan cerdas dalam menanggapi suatu hal.

Ditinjau dari menggalakkan sikap bekerjasama serta saling bantu membantu antara satu sama lain berada pada kategori sangat kuat, ini artinya koperasi sekolah berperan sangat kuat dalam menumbuhkan jiwa wirausaha pada diri siswa di SMK Negeri 1 Gianyar. Siswa selalu bekerjasama dengan teman piketnya untuk melakukan kegiatan yang ad di koperasi sekolah, dan siswa yang menjadi pengurus di koperasi sekolah dituntut untuk saling percaya dalam satu organisasi, maka dengan begitu siswa memiliki sikap yang positif dan mampu mengembangkan ide-ide kreatifnya untuk kemajuan koperasi sekolah dan dirinya sendiri dalam menumbuhkan jiwa wirausahawan. Menurut Cantisa, Herkulana, \& Khosmas (2019) mengungkapkan peran koperasi sekolah pertama yaitu, menumbuhkan jiwa setia kawan, saling menghargai dan gotong royong antar sesama. Kedua menumbuhkan sikap demokrasi, dan kreativitas. Ketiga menerapkan ilmu ekonomi melalui koperasi sekolah.

Ditinjau dari dimensi menumbuhkan bakat kepemimpinan di kalangan generasi muda berada pada kategori sangat kuat, ini berarti koperasi sekolah memiliki peran yang sangat kuat dalam menumbuhkan jiwa wirausahawan pada diri siswa di SMK Negeri 1 Gianyar. 
Menjadi seorang wirausahawan adalah orang yang mampu berdiri sendiri dan mampu menjadi seorang pemimpin dari usahanya, maka koperasi sekolah memberikan pendidikan kepada siswa yaitu menumbuhkan bakat kepemimpinan dalam dirinya. Dalam hal ini siswa diberikan kesempatan untuk menjadi pengurus koperasi sekolah, serta siswa diperbolehkan menitipkan barang atau produknya sendiri untuk dijual di koperasi sekolah, dimana dengan hal ini koperasi sekolah mengajarkan siswa untuk bisa menjadi seorang wirausaha dengan memanfaatkan peluang yang ada dan mampu memimpin usahanya dengan baik. Hal ini sangat penting dilakukan dalam menumbuhkan wirausahawan dengan memberikan pelatihan kepemimpinan, karena tidak semua siswa memiliki jiwa kepemimpinan.

Untuk hal tersebut penting dilakukan evaluasi oleh guru untuk meningkatkan program koperasi sekolah agar siswa bisa lebih percaya diri dalam mengembangkan keterampilan kewirausahaan. Maka dengan adanya koperasi sekolah ini siswa dapat mengetahui kegiatan dan memperoleh pengetahuan dalam mengembangkan jiwa wirausaha yang lebih optimal.

\section{SIMPULAN DAN SARAN Simpulan}

Berdasarkan hasil penelitian dan pembahasan di atas, maka dapat disimpulkan bahwa, koperasi sekolah memiliki 5 (lima) dimensi dalam menumbuhkan jiwa wirausaha yaitu, pertama, membentuk praktik penyelamatan yang baik dan independen dimana memperoleh skor dari responden sebesar 2.220 dengan presentase skor sebesar $81,0 \%$ yang berada pada kategori berperan sangat kuat. Kedua, membantu dalam mewujudkan suasana latihan langsung untuk mempraktikan teknik-teknik pengurusan dan perdagangan memperoleh skor dari responden sebesar 4.069 dengan presentase skor $84,8 \%$ yang berada pada kriteria berperan sangat kuat. Ketiga, mempunyai sifat-sifat serta unsur-unsur demokasi di kalangan generasi yang memperoleh skor sebesar 3.483 dengan presentase skor $84,7 \%$ menunjukkan kategori berperan sangat kuat. Keempat, menggalakkan sikap bekerjasama serta saling bantu membantu antara satu sama lain yang memperoleh skor sebesar 3.540 dengan prsentase skor $86,1 \%$ yang berada pada kriteria berperan sangat kuat. Kelima, menumbuhkan bakat kepemimpinan di kalangan gearasi muda memperoleh skor sebesar 4.109 dengan hasil prsentase skor adalah $85,6 \%$ yang berada pada kriteria berperan sangat kuat.

\section{Saran}

Berdasarkan simpulan di atas, maka dapat diajukan saran sebagai berikut.

Bagi SMK Negeri 1 Gianyar. Berdasarkan hasil penelitian dan temuan di lapangan, koperasi sekolah SMK Negeri 1 Gianyar memiliki peran yang sangat kuat dalam menumbuhkan jiwa wirausahawan pada diri siswa, namun daripada itu masih perlu adanya peningkatan dalam segi kegiatan, seperti siswa diberikan praktek kewirausahaan yang bisa dilakukan di rumah, dimana pihak sekolah bisa memberikan barang atau produk kepada siswa untuk dijual kembali di lingkungan sekitarnya, maka siswa dapat lebih maksimal dalam menumbuhkan jiwa wirausahawan walaupun tidak sedang berada di sekolah.

Guru dapat memberi pembinan kepada siswa bagaimana cara membuat laporan keuangan. Namun perlu adanya partisipasi yang tinggi dari siswa agar koperasi sekolah dapat terus berjalan dengan optimal dalam menumbuhkan jiwa wirausahawan pada siswa.

Saran bagi peneliti lain yang bermaksud ingin mengkaji mengenai peran koperasi sekolah, diharapkan mampu mengembangkan penelitian ini dengan menggunakan populasi dan sampel yang lebih luas agar mendapatkan hasil yang maksimal.

\section{DAFTAR PUSTAKA}

Alma, Buchari. (2004). Kewirausahaan. Bandung: Alfabeta.

Cantisa, M. U., Herkulana, \& Khosmas, F. Y. (2019). Peran Koperasi Sekolah Terhadap Peningkatan Soft Skill Peserta didik di SMK Negeri Pontianak. Pendidikan Dan Pembelajaran, 8(8), 18. 
Hikmawati, F. (2017). Metode Penelitian. Depok: PT. Rajagranfindo Persada.

Ismail, A. M. (2004). Pelajar dalam Gerakan Koprasi Sekolah. Kuala Lumpur: Taman Shamelin Perkasa, cheras.

Kasmir. (2014). Kewirausahaan. Jakarta: Raja Grafindo Persada.

Kurniawan, C. (2014). Peranan Koperasi Sekolah Sebagai Pengembang Keterampilan Kewirausahaan (Chandra Kurniawan). Media Wahana Ekonomika, 11(2), 36-47.

Lindawati Margareta Lilis, \& Suyanto. (2015). Peran Koperasi Sekolah Dalam Meningkatkan Sikap Kewirausahaan Siswa SMK Negeri 1 Wonogiri. Jurnal Pendidikan IPS, 2(2), 170-180.

Firdaus, M. Aziz,. (2012). Metode Penelitian. Tangerang: Jelajah Nusa.

Meredith, G. G. (2000). Kewirausahaan Teori dan Praktek. Jakarta: Pustaka Binaman Pressindo.

Nurbudiyani, I. (2013). Pengembangan Model Kewirausahaan SMK Melalui Koperasi Sekolah. Anterior Jurnal, 12(2), 46-53.

Riduwan. (2008). Metode dan Teknik Menyusun Tesis. Bandung: Alfabeta.

Sapka, M., \& Marazaenal, A. (2019). Peran Koperasi Siswa Dalam Mengembangkan Jiwa Kewirausahaan Siswa SMAN 1 Mataram. Tirai Edukasi, 2(1), 1-10.

Sukidjo, Muhson, A., \& Mustofa. (2016). Jurnal Economia, Volume 12, Nomor 2, Oktober 2016 Koperasi Sekolah Sebagai Wadah Pengembangan Karakter Siswa Sukidjo, Ali Muhson, \& Mustofa. Jurnal Economia, 12(2), 122134.

Suwandi, I. (1986). Seluk Liku Koprasi Sekolah. Jakarta: PT Bhratara Karya Aksara.

Tando, N. M. (2013). Kewirausahaan. Bogor: Inmedia.

Umar, H. (2005). Riset Sumber Daya Manusia dalam Organisasi. Jakarta: PT Gramedia Pustaka Utama. 